\title{
Northern European Trees show a progressively diminishing response to increasing atmospheric carbon dioxide concentrations
}

\author{
J. S. WATERHOUSE, ${ }^{\mathrm{a},}$, V. R. SWITSUR ${ }^{\mathrm{a}, \mathrm{b}}$, A. C. BARKER ${ }^{\mathrm{a}}$, A. H. C. CARTER ${ }^{\mathrm{a}, \mathrm{b}, \dagger}$, \\ D. L. HEMMING ${ }^{\mathrm{c}}$, N. J. LOADER ${ }^{\mathrm{d}}$, and I. ROBERTSON ${ }^{\mathrm{d}, \mathrm{e}}$ \\ ${ }^{a}$ Environmental Sciences Research Centre, Anglia Polytechnic University, \\ Cambridge, CB1 1PT, UK. ${ }^{\mathrm{b}}$ Godwin Institute for Quaternary Research, University of \\ Cambridge CB2 3SA, UK. ${ }^{\mathrm{c}}$ Dept. of Environmental Sciences and Energy Research, \\ Weizmann Institute of Science, Rehovot 76100, Israel. d Department of Geography, \\ University of Wales Swansea, Singleton Park, Swansea SA2 8PP, UK. ${ }^{\text {e }}$ Quaternary \\ Dating Research Unit, CSIR Environmentek, PO Box 395, 0001 Pretoria, South \\ Africa. \\ ${ }^{\dagger}$ Deceased
}

*Corresponding author. Tel.: +44 1223363271 ext. 2169; fax: +44 1223417712 E-mail address: j.s.waterhouse@apu.ac.uk

\begin{abstract}
ABSRACT
In order to predict accurately how elevated atmospheric $\mathrm{CO}_{2}$ concentrations will affect the global carbon cycle, it is necessary to know how trees respond to increasing $\mathrm{CO}_{2}$ concentrations. In this paper we examine the response over the period AD 1895 - 1994 of three tree species growing across northern Europe to increases in atmospheric $\mathrm{CO}_{2}$ concentrations using parameters derived from stable carbon isotope ratios of trunk cellulose. Using the isotope data we calculate values of intrinsic water-use efficiency (IWUE) and intercellular $\mathrm{CO}_{2}$ concentrations in the leaf $\left(\mathrm{c}_{\mathrm{i}}\right)$. Our results show that trees have responded to higher levels of atmospheric $\mathrm{CO}_{2}$ by increasing IWUE whilst generally maintaining constant $c_{i}$ values. However, the IWUE of most of the trees in this study has not continued to rise in line with increasing atmospheric $\mathrm{CO}_{2}$. This behaviour has implications for estimations of future terrestrial carbon storage.
\end{abstract}


Keywords: carbon isotope ratios, intrinsic water-use efficiency, trees, carbon dioxide, atmosphere, Quercus robur, Fagus sylvatica, Pinus sylvestris.

\section{INTRODUCTION}

The annual growth rings of trees provide a uniquely valuable source of past environmental information. They have certain advantages over other proxy sources of environmental data, such as ice-cores from polar and mountainous regions, lake sediments and speleothems, in that tree rings can be dated unambiguously to precise years and that trees grow in a wide range of terrestrial environments. Ring width and latewood densities have been successfully used for climatic reconstruction in areas where tree growth is influenced by one predominant factor such as summer temperature (Briffa et al., 1995) or precipitation (LaMarche, 1974). In temperate regions, tree growth is usually influenced by several factors, and the relationship between ring widths and climatic parameters is weaker. In these regions the ratios of stable isotopes in tree rings have been shown to correlate with climatic parameters such as growing season temperature, relative humidity and precipitation (see Switsur and Waterhouse, 1998, and references therein).

We have previously shown that trees growing in sites in eastern England (Robertson et al. 1997a; Hemming et al., 1998) and southwest Finland (Robertson et al., 1997b) record climatic variables (in particular growing season temperature and relative humidity) in the carbon isotope ratios of $\alpha$-cellulose extracted from annual growth rings. In this paper we reassess these carbon stable isotope records, which extend 
over most of the last century, in order to gain insight into trees' response to increasing atmospheric carbon dioxide concentrations and how this response varies with site conditions and atmospheric $\mathrm{CO}_{2}$ concentrations.

Plants respond to increasing levels of atmospheric carbon dioxide in several ways. Experimental results (Morison, 1993; Polley et al., 1993; Picon et al., 1996) and theoretical models (Beerling, 1994; Thornley \& Gannell, 1996; Cao \& Woodward, 1998) indicate that plants are able to increase their water-use efficiency (WUE) as $\mathrm{CO}_{2}$ levels rise. Short term experimental results from studies of plants in growth chambers, however, may not reliably predict the behaviour of mature trees growing in their natural environment, as trees are able adjust their physiological response over time to gradually increasing $\mathrm{CO}_{2}$ concentrations. As shown below, intrinsic wateruse efficiency (IWUE) can be calculated from values of stable carbon isotope ratios from tree organic matter, and these values can give insight into how naturallygrowing trees respond, or have responded, to increasing atmospheric $\mathrm{CO}_{2}$ concentrations. Studies of this nature have been carried out on freely growing trees in the USA (Marshall \& Monserud, 1996; (Feng, 1998, 1999; Tang et al., 1999), Québec (Watmough et al., 2001), Tasmania (Francey \& Farquhar, 1982) and France (Bert et al., 1997 and Duquesnay et al., 1998) and have revealed that trees vary in their responses to increasing atmospheric $\mathrm{CO}_{2}$ concentrations.

Isotopic discrimination $\left(\Delta^{13} \mathrm{C}\right)$ between carbon of atmospheric $\mathrm{CO}_{2}$ and plant carbon for $\mathrm{C}_{3}$ plants is defined in equation 1 : 


$$
\Delta^{13} \mathrm{C}=\left(\delta^{13} \mathrm{C}_{\mathrm{a}}-\delta^{13} \mathrm{C}_{\mathrm{p}}\right) /\left(1+\delta^{13} \mathrm{C}_{\mathrm{p}} / 1000\right)
$$

where $\delta^{13} \mathrm{C}_{\mathrm{a}}$ and $\delta^{13} \mathrm{C}_{\mathrm{p}}$ are the isotopic ratios of carbon $\left({ }^{13} \mathrm{C} /{ }^{12} \mathrm{C}\right)$ in atmospheric $\mathrm{CO}_{2}$ and plant material respectively expressed in parts per mille (\%o) relative to VPDB. $\Delta^{13} \mathrm{C}$ is related to the ratio between the intercellular $\left(\mathrm{c}_{\mathrm{i}}\right)$ and atmospheric $\left(\mathrm{C}_{\mathrm{a}}\right)$ concentrations (mole fractions) of $\mathrm{CO}_{2}$ as expressed by equation 2 (Farquhar et al., 1989):

$$
\Delta^{13} \mathrm{C}=a+(b-a) \mathrm{c}_{\mathrm{i}} / \mathrm{c}_{\mathrm{a}}
$$

where $a$ is the discrimination due to diffusion of $\mathrm{CO}_{2}$ in air (4.4\%) and $b$ is the discrimination during carboxylation for $C_{3}$ plants (28\%o) (Brugnoli et al., 1998). IWUE is defined as the ratio of assimilation rate (A) for uptake of $\mathrm{CO}_{2}$ to leaf conductance to water vapour $\left(g_{w}\right)$ (Ehleringer, 1993). Since $g_{w}=1.6 g_{c}\left(g_{c}\right.$ is the stomatal conductance to $\mathrm{CO}_{2}$ ), and $\mathrm{A}, \mathrm{g}_{c}, \mathrm{C}_{\mathrm{a}}$ and $\mathrm{c}_{\mathrm{i}}$ are related through Fick's Law, A $=g_{c}\left(c_{a}-c_{i}\right)$, it is possible to calculate values of IWUE from values of $\Delta^{13} \mathrm{C}$ (equation 3).

$$
\text { IWUE }=c_{\mathrm{a}}\left(b-\Delta^{13} \mathrm{C}\right) / 1.6(b-a)
$$


[IWUE is equal to instantaneous water-use efficiency (instWUE) (determined by leaf gas exchange) multiplied by the difference in water vapour mole fraction between leaf and atmosphere. Units of IWUE are those of $\mathrm{CO}_{2}$ mole fraction $\left(\mu \mathrm{mol} \mathrm{mol}{ }^{-1}\right)$; those of instWUE are $\mu \mathrm{mol} \mathrm{CO}_{2} / \mathrm{mol} \mathrm{H}_{2} \mathrm{O}$. The advantage of IWUE over instWUE is that the former allows assessment of the role of biological components in determining water-carbon exchange relationships independently of changing atmospheric conditions (Ehleringer, 1993).]

\section{SITES AND METHODS}

Values of IWUE were calculated for trees of three species: pedunculate oak (Quercus robur L.), common beech (Fagus sylvatica L.) and Scots pine (Pinus sylvestris L.). The trees were from three geographical regions in northern Europe: northwest Norfolk, south Bedfordshire (both in eastern England) and southwest Finland (Table 1). In two of the regions (northwest Norfolk and southwest Finland), sites with differing hydrological regimes and soil types were selected; these are classed as 'dry' and 'wet' as appropriate. In northwest Norfolk, the dry site (NORD) is on freely draining lower Cretaceous sands, while the wet site (NORW) occupies the often waterlogged flood plain of the River Babingley, some 3km south of the dry site. The dry site in southwest Finland (FIND) sits astride a rock-strewn area of freely draining glacial drift; the nearby wet site (FINW) on lower ground is underlain by argillaceous marine clays and silts. Confirmation of the difference in hydrologies between the two Finnish sites is provided by soil moisture analysis (Barker, 2000), which showed that the soil moisture content at FINW was 50\% greater than that at FIND down to a depth of $0.5 \mathrm{~m}$. The differences in hydrology between sites enabled us to investigate the effects of changing water availability on tree response to increasing $c_{a}$ under the same 
local climatic conditions. Oaks were sampled in all regions, whereas Scots pine and beech were sampled in south Bedfordshire only; thus we can compare variations of one species across geographical regions and the behaviour of three species in one location. All the trees selected were over 150 years old. In order to minimize complications arising from the juvenile effect, which produces more negative values of $\delta^{13} \mathrm{C}$ in wood produced during the first few decades of growth (Freyer \& Belacy, 1983) as a result of assimilating respired $\mathrm{CO}_{2}$ depleted in ${ }^{13} \mathrm{C}$ (Keeling, 1961) or reduced light levels lower in the canopy (Heaton, 1999), we sampled the most recent 100 years of annual rings.

We measured the carbon isotope ratios of samples of $\alpha$-cellulose $\left(\delta^{13} \mathrm{C}_{\text {cell }}\right)$ extracted from the latewood of annual rings for the period 1895-1994 for both oak and Scots pine as previously described (Loader et al., 1997; Robertson et al., 1997a,b; Hemming et al., 1998), and hence calculated values of IWUE correspond to the period of latewood formation for these species. As the beech is a diffuse porous species, it was not possible to distinguish and separate latewood from earlywood unambiguously from each growth ring, and therefore the whole ring was sampled. For each species at each site, annual values of $\delta^{13} \mathrm{C}_{\text {cell }}$ were calculated as an average for the number of trees samples (Table 1) and annual values of IWUE were calculated from these according to Equation 3. Values of $\delta^{13} \mathrm{C}_{\mathrm{a}}$ and $\mathrm{c}_{\mathrm{a}}$ for each year were determined as previously described (see Hemming et al., 1998 for details) using ice-core data from Antarctica and measured atmospheric data from Antarctica and Europe. 
A number of possible sources of error needs to be considered. Values of $\delta^{13} \mathrm{C}_{\mathrm{p}}$ in equations 2 and 3 ought, strictly speaking, to refer to initial photosynthate in the leaf, (Heaton, 1999) and not cellulose in the trunk. Using $\delta^{13} \mathrm{C}_{\text {cell }}$ in place of $\delta^{13} \mathrm{C}_{\mathrm{p}}$ may therefore introduce some bias into calculated values of IWUE and $\mathrm{c}_{\mathrm{i}}$. Wood cellulose is generally enriched in ${ }^{13} \mathrm{C}$ relative to leaf cellulose, with an enrichment value of 34\%o reported for juniper (J. monosperma) from Arizona (Leavitt and Long, 1982), although the degree of enrichment may be dependent upon species (Schleser,1990; White et al., 1993). Leaf tissue is formed early in the growing season, when values of $\mathrm{C}_{\mathrm{i}} / \mathrm{C}_{\mathrm{a}}$ values are relatively high, resulting in correspondingly low values of $\delta^{13} \mathrm{C}$ (Francey et al. 1985; Jäggi et al., 2002). Feng $(1998,1999)$ argues that wood in the trunk formed later in the season originates from exported carbohydrate formed in mature leaves within which $\mathrm{c}_{\mathrm{i}} / \mathrm{c}_{\mathrm{a}}$ attains lower values; hence $\delta^{13} \mathrm{C}$ values of leaf photosynthate are closer to those of trunk wood, the $\delta^{13} \mathrm{C}$ value of which can therefore legitimately be used for calculation of IWUE. Moreover, with the exception of beech, we measure $\delta^{13} \mathrm{C}$ values in the latewood only, hence differences in leaf and wood $\delta^{13} \mathrm{C}$ should be minimized further. Even if using values of $\delta^{13} \mathrm{C}_{\text {cell }}$ to calculate IWUE does produce a bias in the calculated values, it does not alter their temporal trends, which form the main subject of this paper.

Another factor that should be considered is that the carbon dioxide sampled by trees may not have values of $\delta^{13} \mathrm{C}$ that are the same as that of the general atmosphere $\left(\delta^{13} \mathrm{C}_{\mathrm{a}}\right.$ ) owing to mixing of respired $\mathrm{CO}_{2}$ into the local atmosphere sampled by the tree. This effect is likely to be much more important for young trees growing below the canopy and is minimized in this study by exclusion of at least the first 50 years of 
growth. Also, trees from the NORD and BEDS sites are growing in open environments, and hence likely to be sampling $\mathrm{CO}_{2}$ with $\delta^{13} \mathrm{C}$ value close to $\delta^{13} \mathrm{C}_{\mathrm{a}}$; however, this may not be the case for the more wooded sites of FIND, FINW and NORW.

\section{RESULTS AND DISCUSSION}

Annual values of IWUE for each species at each site (calculated from equations 1 and 3) are shown in Fig. 1. The high frequency fluctuations, which are similar for trees from the same site, reflect the high correlation between $\delta^{13} \mathrm{C}_{\text {cell }}$ and local climatic parameters (e.g. summer temperature, humidity and precipitation) and the effects of climatic conditions on isotopic discrimination (for full details of these climatic relationships see Hemming et al., 1998; Robertson et al. 1997a; Robertson et al. 1997b). It is evident from Fig. 1 that all species at all the sites show a long-term increase in their values of IWUE during the past century.

The main cause of this common behaviour is likely to be the increase in atmospheric $\mathrm{CO}_{2}$ concentration, although changing parameters that can influence IWUE through their effects on stomatal aperture, and hence $\Delta^{13} \mathrm{C}$, might also play a part. Of the three meteorological parameters available at all geographical locations in this study (temperature, precipitation and relative humidity) it is relative humidity that has shown the most significant change in two of regions: Norfolk and southwest Finland 
(Fig. 2a and c); however, there has been no significant decrease in relative humidity in Bedfordshire (Fig. 2b). Previous analysis has shown that relative humidity or the derived vapour pressure deficit also has the strongest relationship with carbon isotope ratios in all three regions (Robertson et al. 1997a, Robertson et al., 1997b Hemming et al., 1998); therefore the possible effect of this parameter alone on values of IWUE are explored here. Average changes in relative humidity are very similar in Norfolk and southwest Finland: 7\% (since 1920) and 8\% (since 1895) respectively. The isotopic discrimination/relative humidity coefficients (obtained by linear regression analysis) are also very similar: $0.065 \%$ o/\% for Norfolk, $0.074 \%$ o/\% for Finland. Although there is much uncertainty involved in this analysis, the observed changes in relative humidity might therefore be responsible for an increase in $\Delta^{13} \mathrm{C}$ of about $0.5 \%$ at the two sites, through its effects on stomatal aperture (Beerling, 1996). This would lead to an increase in IWUE (Equation 3) of about 4-5 $\mu \mathrm{mol} \mathrm{mol}^{-1}$ over the period of study for trees from these two sites. Other factors may also play a role; for example, recent studies (Keiller and Holmes, 2001) have demonstrated that increased UV-B has profound effects on stomatal density and function.

The percentage increase in calculated values of IWUE ranges from $c a$. 24\% for oaks from NORD to $c a .48 \%$ for beech from BEDS, with most of the increase occurring since 1930. These values are comparable to the 30\% increase in IWUE from 1930s1980s reported for Abies alba in eastern France (Bert et al.,1997). The value for beech from BEDS (ca. 48\%) falls just outside the increases since 1900 reported for beech in north eastern France (23\%-44\%) (Duquesnay et al., 1998). It should be noted that neither Bert et al (1997) nor Dusquesnay et al. (1998) make allowance for 
any changes in meteorological parameters over their periods of study, so we compare our calculated values of IWUE directly with theirs. The fact that beech shows a stronger IWUE response than the oak or pine may be due to the particularly droughtsensitive nature of this species, caused by a relatively shallow rooting depth. Our measured increases in IWUE are in the range of values predicted from theoretical models (Beerling, 1994; Thornley \& Gannell, 1996). However, the increases in IWUE displayed by our oaks are significantly higher than would be predicted from the results obtained from growing Q. robur seedlings in $\mathrm{CO}_{2}$ concentration of 350 and $700 \mu \mathrm{mol} \mathrm{mol}{ }^{-1}$ (Picon et al., 1996) even when a reduction of $\sim 4-5 \mu \mathrm{mol} \mathrm{mol}{ }^{-1}$ is made to the overall increase in IWUE that may result from decreasing humidity in Norfolk and southwestern Finland. Our findings therefore support the caution expressed in scaling up results from growth chambers experiments to mature trees growing under natural conditions (Thornley \& Gannell, 1996; Ceulemans \& Mousseau, 1994; Shugart et al., 1986).

Although the trees in this study show an overall increase in IWUE as expected, graphs of IWUE plotted against $c_{a}$ (Fig. 3) show that the rate of increase in IWUE reduces at higher values of $c_{a}$, indicating lower sensitivities to increasing levels of $\mathrm{CO}_{2}$. Such behaviour at ambient values of $\mathrm{c}_{\mathrm{a}}$ is not a feature of current models. The reduction in response is most clearly marked in the oaks from BEDS; but even at the other two locations reduction in response to increasing $\mathrm{CO}_{2}$ concentrations might be greater than is suggested by Fig. 3 if decreasing humidity is affecting IWUE as discussed above. Figs. 2a and 2c show that relative humidity has been falling at an increasing rate in recent years at the sites in southwestern Finland and particularly in Norfolk. As discussed above, this could increase the value of IWUE by around 4-5 
$\mu \mathrm{mol} \mathrm{mol}{ }^{-1}$ over the period of study, with most of it occurring in more recent years, precisely where we observe the decreasing trends in IWUE in Fig. 3.

The relative behaviour of the trees seems to depend upon local site conditions. This can be seen in the oaks from NORD and NORW. Although the dry and wet sites are only $3 \mathrm{~km}$ apart, and hence subject to the same macro-climatic conditions, the trees from the dry site show a lower response to increasing $c_{a}$ than the trees from the wet site. Such contrasting behaviour accords with growth chamber experiments (Picon et al., 1996) in which well watered oak seedlings increased their WUE more than twice as much as droughted seedlings as $\mathrm{C}_{\mathrm{a}}$ increased from 350 to $700 \mu \mathrm{mol} \mathrm{mol}{ }^{-1}$. The similarity in response of trees from BEDS and NORD may reflect the similarity in soil drainage at the two sites, in contrast with the wetter site at NORW. Oaks from FIND and FINW, however, seem to behave more similarly, with perhaps a lower sensitivity to increasing $c_{a}$ shown by trees at the wet site in this case. This suggests either that, despite differences in hydrology, water-stress is not significantly different between the two Finnish sites, or that water-stress is not the dominant limiting factor.

Higher IWUE can result from increasing A or decreasing $g_{w}$ or a combination of these factors. It is not possible to estimate the balance of factors in our trees, although reported concurrent increases in A and decreases in $\mathrm{g}_{\mathrm{w}}$ for $\mathrm{Q}$. robur grown under increasing $\mathrm{c}_{\mathrm{a}}$ (Picon et al., 1997; Beerling et al., 1996) suggest that both factors play a role and are inherently linked. The response of $g_{w}$ to increasing $c_{a}$, however, may vary with species and conditions of water stress at the leaf level. Heath (1998) reported that young oak consistently decreased the value of $\mathrm{g}_{\mathrm{w}}$ in elevated $\mathrm{CO}_{2}$, 
whereas the response of beech depended on the leaf-to-air vapour pressure deficit, at high levels of which $\mathrm{g}_{\mathrm{w}}$ of beech was unchanged in conditions of elevated $\mathrm{CO}_{2}$.

Fig. 4 shows values of $c_{i}$ calculated from equation 2 . The trees in this study seem generally to be adopting a strategy of homeostatic maintenance of $c_{i}$ levels against increasing $c_{a}$, at least until the mid 1970s. This behaviour contrasts with evidence for the maintenance of constant $\mathrm{c}_{\mathrm{i}} / \mathrm{C}_{\mathrm{a}}$ in plants as $\mathrm{C}_{\mathrm{a}}$ rises (Morison, 1993; Morison, 1987; Farquhar and Sharkey, 1982) and for increasing values of $\mathrm{c}_{\mathrm{i}}$ from AD 1800 displayed by a selection of trees growing in western North America (Feng, 1998). Subtle differences are evident between species and sites. In particular, after the mid 1970s, oaks at NORD and BEDS show $\mathrm{c}_{\mathrm{i}}$ increasing to values above the average for that of previous decades; this occurs concurrently with levelling IWUE values. The behaviour of $\mathrm{c}_{\mathrm{i}}$ and IWUE over this period may be linked to the effect of carbon dioxide concentration on two processes in $C_{3}$ plants. One of these processes is the observed reduction in stomatal index and stomatal density, which reach lower limits in Q. petraea (Kürschner et al., 1996) and Q. robur (Beerling et al., 1996) respectively at $c_{a}$ values above $c a .340 \mathrm{mmol} \mathrm{mol}^{-1}$. The other is the biphasic nature of the response of A to increasing $\mathrm{C}_{\mathrm{a}}$ (Woodward et al., 1991; von Caemmerer and Farquhar 1981): an intially linear increase in A curves less steeply at higher values of $c_{a}$. The deviation from linearity occurs at $c_{a}$ values that depend upon conditions and species, but it has been observed at $\mathrm{c}_{\mathrm{a}}$ values as low as ca. $330 \mu \mathrm{mol} \mathrm{mol}^{-1}$ (von Caemmerer \& Farquhar, 1981).

Our results, supported by those of other researchers, suggest that trees in different localities may be responding to increasing $c_{a}$ by adopting different homeostatic set 
points. Leavitt \& Lara (1994) reported constant values for $\mathrm{c}_{\mathrm{i}} / \mathrm{c}_{\mathrm{a}}$ over the same period for Fitzroya cupressoides in Chile; whereas Marshall \& Monserud (1996) found that conifers in northern Idaho, USA, had maintained constant values of $c_{a}-c_{i}$ (equivalent to IWUE) throughout the past century. In agreement with our observations, Francey and Farquhar (1982) reported the maintenance of $c_{i}$ values of Tasmanian trees from 1870-1970. The reasons for the differences in behaviour are almost certainly related to local external factors, particularly to the availability of moisture and nutrients (Duquesnay et al., 1998; Shugart et al., 1986). It seems, however, that trees worldwide are adapting to increasing levels of atmospheric $\mathrm{CO}_{2}$ in different ways. The reduction in sensitivity of IWUE to increasing $c_{a}$ shown by most of the trees in this study may be related to the loss in climatic sensitivity of latewood relative densities in recent years reported by Briffa and co-workers (1998). Whether this reduction in the rate of increase of IWUE is merely a temporary phenomenon remains to be seen; but it could represent a saturation effect. Such an effect, at comparatively low values of $\mathrm{C}_{\mathrm{a}}$, is neither observed in growth chamber experiments nor predicted by current models, which predict a continuing rise in terrestrial carbon storage as a result of the combined effects of $\mathrm{CO}_{2}$ fertilization and climate change as $\mathrm{c}_{\mathrm{a}}$ increases (Cao and Woodward, 1998; Melillo et al., 1996). If a long-term or permanent reduction in sensitivity to atmospheric $\mathrm{CO}_{2}$ is established for a significant proportion of trees in temperate regions, the degree of future terrestrial carbon storage will have been greatly overestimated.

Note: This paper is dedicated to the memory of our colleague, Tony Carter, 19312003 


\section{ACKNOWLEDGEMENTS}

We thank Fritz Schweingruber for advice on site selection, Mike Hall for help with mass spectrometry, James Rolfe for technical assistance, and Don Keiller and Richard West for useful discussions. This work was supported by a research studentship form the NERC and grants from the European Commission (EV5V-CT94-0500, EVK2CT-2002-00136 and EVK2-CT-2002-00147).

\section{References}

Barker, A.C., 2000. Tree Ring Evidence of Climatic Change in Northern Eurasia. Unpublished Ph.D. Thesis, Anglia Polytechnic University.

Beerling, D.J., 1994. Predicting leaf gas exchange and $\delta^{13} \mathrm{C}$ responses to the past 30,000 years of global environmental change. New Phytologist 128, 425-433.

Beerling, D.J., 1996. ${ }^{13} \mathrm{C}$ discrimination by fossil leaves during the late-glacial oscillation 12-10 ka BP: measurements and physiological controls. Oecologia 108, 29-37.

Beerling, D.J., Heath J., Woodward, F.I., Mansfield, T.A., 1996. Drought-CO $\mathrm{CO}_{2}$ interactions in trees: observations and mechanisms. New Phytologist 134, 235242.

Bert, D., Leavitt, S.W., Dupouey, J.-L., 1997. Variations of wood $\delta^{13} \mathrm{C}$ and water-use efficiency of Abies alba during the last century. Ecology 78, 1588-1596. 
Briffa, K.R., Schweingruber, F.H., Jones, P.D., Osborn, T.J., Shiyatov, S.G., Vaganov, E.A., 1998. Reduced sensitivity of recent tree-growth to temperature at high northern latitudes. Nature 391, 678-682.

Briffa, K.R., Jones, P.D., Schweingruber, F.H., Shiyatov, S.G., Cook, E.R., 1995. Unusual twentieth-century summer warmth in a 1,000-year temperature record from Siberia. Nature 376, 156-158.

Brugnoli, E., Scartazza, A., Lauteri, M., Monteverdi, M.C., Máguas, C., 1998.

Carbon isotope discrimination in structural and non-structural carbohydrates in relation to productivity and adaptation to unfavourable conditions. In: Griffiths, H. (Ed.), Stable Isotopes . BIOS Scientific Publishers Ltd., Oxford, 133-146.

Cao, M., Woodward, F.I., 1998. Dynamic responses of terrestrial ecosystem carbon cycling to global climate change. Nature 393, 249-252.

Carter, A.H.C., Robertson, I. 1998. Relative humidity - a data set for east England. Weather 53, 181-189.

Ceulemans, R., Mousseau, M., 1994. Effects of elevated atmospheric $\mathrm{CO}_{2}$ on woody plants. New Phytologist 127, 425-446.

Duquesnay, A., Bréda, N., Stievenard, M., Dupouey, J.L., 1998. Changes of tree-ring $\delta^{13} \mathrm{C}$ and water-use efficiency of beech (Fagus sylvatica L.) in north-east France during the past century. Plant, Cell and Environment 21, 565-572.

Ehleringer, J.R., 1993. Carbon and water relations in desert plants: an isotopic perspective. In: Ehleringer, JR., Hall, J.R., Farquhar, G.D. (Eds.), Stable Isotopes and Plant Carbon-Water Relations. Academic Press, San Diego, 155-172.

Farquhar, G.D., Sharkey, T.D., 1982. Stomatal conductance and photosynthesis. Annual Reviews of Plant Physiology 33, 317-345. 
Farquhar, G.D., Ehleringer, J.R., Hubick, K.T., 1989. Carbon isotope discrimination and photosynthesis. Annual Reviews of Plant Physiology and Plant Molecular Biology 40, 503-537.

Feng, X., 1998. Long-term $\mathrm{c}_{\mathrm{i}} / \mathrm{c}_{\mathrm{a}}$ response of trees in western North America to atmospheric $\mathrm{CO}_{2}$ concentrations derived from carbon isotope chronologies. Oecologia 117, 19-25.

Feng, X., 1999. Trends in intrinsic water-use efficiency of natural trees for the past 100-200 years: A response to atmospheric $\mathrm{CO}_{2}$ concentrations. Geochimica et Cosmochimica Acta 63, 1891-1903.

Francey, R.J., Farquhar, G.D., 1982. An explanation of ${ }^{13} \mathrm{C} /{ }^{12} \mathrm{C}$ variations in tree rings. Nature, 297, 28-31.

Francey, R.J., Gifford, R.M., Sharkey, T.D. Weir, B., 1985. Physiological influences on carbon isotope discrimination in huon pine (Lagarostobos franklinii). Oecologia 66, 211-218.

Freyer, H.D., Belacy, N., 1983. ${ }^{13} \mathrm{C} /{ }^{12} \mathrm{C}$ records in Northern Hemisphere trees during the past 500 years - anthropogenic impact and climatic superpositions. Journal of Geophysical Research 88(C11), 6844-6852.

Heath, J., 1998. Stomata of trees growing in $\mathrm{CO}_{2}$-enriched air show reduced sensitivity to vapour pressure deficit and drought. Plant, Cell and Environment 21, 1077-1088.

Heaton, T.H.E., 1999. Spatial, species, and temporal variations in the ${ }^{13} \mathrm{C} /{ }^{12} \mathrm{C}$ ratios of $\mathrm{C}_{3}$ plants: implications for palaeodiet studies. Journal of Archaeological Science 26, 637-649.

Heino, R., 1994. Climate in Finland during the period of meteorological observations. Finnish Meteorological Institute Contributions 12, Helsinki, pp. 24-88. 
Hemming, D.L., Switsur, V.R., Waterhouse, J.S., Heaton, T.H.E., Carter A.H.C., 1998. Climatic variation and the stable carbon isotope composition of tree ring cellulose: an intercomparison of Quercus robur, Fagus sylvatica and Pinus silvestris. Tellus 50B, 25-33.

Jäggi, M., Saurer, M., Fuhrer, J., Siegwolf, R., 2002. The relationship between the stable carbon isotope composition of needle bulk material, starch, and tree rings

in Picea abies. Oecologia 131, 325-332.

Keeling, C.D., 1961. The concentration and isotopic abundances of atmospheric carbon dioxide in rural and marine air. Geochimica et Cosmochimica Acta 24, 277-298.

Keiller, D.R., Holmes, M.G., 2001. Effects of long-term exposure to elevated UV-B on the photosynthetic performance of five broad-leaved tree species. Photosynthesis Research 67, 229-40.

LaMarche, V.C. Jr., 1974. Paleoclimatic inferences from long tree-ring records. Science 183, 1043-1048.

Leavitt, S.W., Long A., 1982. Evidence for ${ }^{13} \mathrm{C} /{ }^{12} \mathrm{C}$ fractionation between tree leaves and wood. Nature 298, 742-744.

Leavitt, S.W., Lara, A., 1994. South American tree rings show declining $\delta^{13} \mathrm{C}$ trend. Tellus 46B, 152-157.

Loader, N.J., Robertson, I., Barker, A.C., Switsur, V.R., Waterhouse, J.S., 1997. An improved method for the batch processing of small wholewood samples to $\alpha$ cellulose. Chemical Geology 136, 313-317.

Marshall, J.D., Monserud, R.A., 1996. Homeostatic gas-exchange parameters inferred from ${ }^{13} \mathrm{C} /{ }^{12} \mathrm{C}$ in tree rings of conifers. Oecologia $105,13-21$. 
Melillo. J.M., Prentice, I.C., Farquhar, G.D., Schulze, E.-D., Sala, O.E., 1996.

Terrestial biotic responses to environmental change and feedbacks to climate. In: Houghton J.T., Meira Filho, L.G., Callander, B.A., Harris, N., Kattemberg, A., Maskell, K. (Eds.), Climate Change 1995. Cambridge University Press, Cambridge, 445-481.

Morison, J.I.L., 1987. Intercellular $\mathrm{CO}_{2}$ concentration and stomatal resplonse to $\mathrm{CO}_{2}$. In: Zeigler E, Cowan, I., Farquhar, G.D. (Eds)., Stomatal Function, Stanford University Press, Stanford, 251-229.

Morison, J.I.L., 1993. Response of plants to $\mathrm{CO}_{2}$ under water limited conditions. Vegetatio 104, 193-209.

Picon, C., Ferhi, A., Guehl, J.M., 1997. Concentration and $\delta^{13} \mathrm{C}$ of leaf carbohydrates in relation to gas exchange in Quercus robur under elevated $\mathrm{CO}_{2}$ and drought. Journal of Experimental Botany 48, 1547-1556.

Picon, C., Guehl, J.M., Aussenac, G., 1996. Growth dynamics, transpiration and water-use efficiency in Quercus robur plants submitted to elevated $\mathrm{CO}_{2}$ and drought. Annales des Sciences Forestières 53, 431-446.

Polley, H.W., Johnson, H.B., Marino, B.D., Mayeux, H.S., 1993. Increase in C3 plant water-use efficiency and biomass over Glacial to present $\mathrm{CO}_{2}$ concentrations. Nature 361, 61-64.

Robertson, I., Switsur, V.R., Carter, A.H.C., Barker, A.C., Waterhouse, J.S., Briffa, K.R., Jones, P.D., 1997a. Signal strength and climate relationships in ${ }^{13} \mathrm{C} /{ }^{12} \mathrm{C}$ ratios of tree ring cellulose from oak in east England. Journal of Geophysical Research 102(D16), 19507-19516.

Robertson, I., Rolfe, J., Switsur, V.R., Carter, A.H.C., Hall, M.A., Barker, A.C., Waterhouse, J.S., 1997b. Signal strength and climate relationships in ${ }^{13} \mathrm{C} /{ }^{12} \mathrm{C}$ 
ratios of tree ring cellulose from oak in southwest Finland. Geophysical Research Letters 24, 1487-1490.

Schleser, G.H., 1990.Investigations of the $\delta^{13} \mathrm{C}$ pattern in leaves of Fagus sylvatica L. Journal of Experimental Botany 41, 565-572.

Shugart, H.H., Antonovsky, M.Ya., Jarvis, P.G., Sandford, A.P., 1986. CO CO $_{2}$ climate change and forest ecosystems. In: Bolin, B., Döös, B.R., Jäger, J., Warrick, R.A. (Eds.), The Greenhouse Effect, Climatic Change, and Ecosystems, John Wiley \& Sons, 475-521.

Switsur, R., Waterhouse, J., 1998. Stable isotopes in tree ring cellulose. In: Griffiths, H. (Ed.), Stable Isotopes: Integration of Biological, Ecological and Geochemical Processes, BIOS Scientific Publishers Ltd., Oxford, 303-321.

Tang, K., Feng, X., Funkhouser, G., 1999. The $\delta^{13} \mathrm{C}$ of tree rings in full-bark and strip-bark bristlecone pine trees in the White Mountains of California. Global Change Biology 5, 33-40.

Thornley, H.M., Cannell, M.G.R., 1996. Temperate forest responses to carbon dioxide, temperature and nitrogen: a model analysis. Plant, Cell and Environment 19, 1331-1348.

von Caemmerer, S., Farquhar, G.D., 1981. Some relationships between the biochemistry of photosynthesis and the gas exchange of leaves. Planta 153, 376-387.

Watmough, S.A., McNeely, R., LaFleure, P.M. 2001. Changes in wood and foliar $\delta^{13} \mathrm{C}$ in sugar maple at Gatineau Park, Quebec, Canada. Global Change Biology 7, 955-960.

White, J., Molfino, B., Labeyrie, L., Stauffer, B. and Farquhar, G., 1993. How reliable and consistent are paleodata from continents, oceans, and ice? In: Eddy, 
J.A., Oeschger, H. (Eds.), Global Changes in the Perspective of the Past, John Wiley, Chichester, pp. 73-102.

Woodward, F.I., Thompson, G.B., McKee, I.F., 1991. The effects of elevated concentrations of carbon dioxide on individual plants, populations, communities and ecosystems. Annals of Botany 67, 23-38. 
Table 1. Sites and trees

\begin{tabular}{|c|c|c|c|c|}
\hline Site & Latitude & Longitude & Species & $\mathrm{N}^{2}$ \\
\hline $\begin{array}{l}\text { Northwest Norfolk, } \\
\text { England }\end{array}$ & $52^{\circ} 50^{\prime} \mathrm{N}$ & $0^{\circ} 30^{\prime} \mathrm{E}$ & & \\
\hline${ }^{\prime} d r y^{\prime \dagger}$ (NORD) & & & Quercus robur & 5 \\
\hline 'wet' ${ }^{\dagger}(\mathrm{NORW})$ & & & Quercus robur & 5 \\
\hline South Bedfordshire, & $52^{\circ} 00^{\prime} \mathrm{N}$ & $0^{\circ} 35^{\prime} \mathrm{W}$ & Quercus robur & 2 \\
\hline England (BEDS) & & & Fagus sylvatica & 2 \\
\hline & & & Pinus sylvestris & 2 \\
\hline Turku, Southwest & $60^{\circ} 25^{\prime} \mathrm{N}$ & $22^{\circ} 10^{\prime} \mathrm{E}$ & & \\
\hline Finland & & & & \\
\hline 'dry' ${ }^{\dagger}$ (FIND) & & & Quercus robur & 5 \\
\hline${ }^{\prime}$ wet $^{\dagger \dagger}$ (FINW) & & & Quercus robur & 5 \\
\hline
\end{tabular}

\footnotetext{
${ }^{*} \mathrm{~N}$ is no. of trees used for isotope measurements

† The terms 'dry' and 'wet' were assigned on the basis of the hydrological regimes at each site (soil type and drainage) and not on precipitation (see Robertson et al.,1997a,b for details).
} 


\section{Figure Legends:}

Figure 1 Annual values of IWUE. Values of IWUE are calculated using equations (1) - (3) from mean values of $\delta^{13} \mathrm{C}_{\text {cell }}$ measured for trees at each site (see Table). Second order polynomial trend lines are shown.

Figure 2 Average relative humidity together with second order polynomial trend lines for (a) Norfolk and (b) Bedfordshire and (c) southwest Finland. For Norfolk, relative humidity values (10.00 a.m.) are from the combined Cranwell-Waddington record from 1920 (Carter and Robertson, 1998). For Bedfordshire, relative humidity values (9.00 a.m.) are from Rothamsted Experimental Station, Harpenden, Hertfordshire from 1915. For Finland, relative humidity values (2.00 p.m.) are from Turku meteorological record from 1895 (Heino, 1994; Robertson et al., 1997b).

Figure 3 Annual values of IWUE, calculated as for Figure 1, plotted against values of atmospheric carbon dioxide concentrations. Second order polynomial trend lines are shown.

Figure 4 Annual values of intercellular $\mathrm{CO}_{2}$ concentrations $\left(\mathrm{c}_{\mathrm{i}}\right)$ calculated from annual values of $\delta^{13} \mathrm{C}_{\text {cell }}$ determined as in Figure 1. 